\title{
Bridging the gap. The Mesolithic-Neolithic transition in a frontier zone
}

\author{
Bart Vanmontfort \\ Faculty of Archaeology, Leiden University, The Netherlands \\ bart.vanmontfort@geo.kuleuven.be
}

\begin{abstract}
This paper deals with the chronological hiatus in the Neolithic sequence of the southern part of the Low Countries. It can at present only be bridged indirectly, by a detailed analysis of the situation prior to and after the gap. The focus in this paper is on the nature of the Neolithic and its relationship with possible native non-Neolithic populations. The results of this analysis show the transition process to have been more than a simple and unidirectional 'Neolithisation'.

IZVLEČEK - Članek obravnava kronološki hiatus v neolitski sekvenci južnega dela na nižinskem puhličnem področju severozahodne Evrope. Tega trenutno lahko premostimo le s podrobno analizo situacije pred in po vrzeli. V članku se ukvarjamo z neolitikom in razmerjem med neolitskimi in morebitnim avtohtonim, ne-neolitskim prebivalstvom. Rezultati analize kažejo, da je bil proces tranzicije več kot preprosta in enosmerna neolitizacija.
\end{abstract}

KEY WORDS - Mesolithic-Neolithic transition; Linearbandkeramik; Chasséen and Michelsberg Culture; Contact finds; Settlement patterns

\section{Introduction}

The past decade of research on the Mesolithic/Neolithic transition in Europe has shown this transition to have been a 'mosaic' of processes and interactions rather than a single and clear-cut transition process (e.g. Tringham 2000). It varies greatly in different parts of Europe with regard to its timing, contact situations and the transition processes at work. A leading thread is the local impact of the Neolithic and the archaeological result entailing the end of traditional hunter-gatherer communities. This is the case all over Europe, including Scandinavia, the British Isles and Ireland (Fig. 1). Apparently, the advent of the Neolithic signified the start of a new way of life, no matter what transitional processes or temporal delays involved.

The loess belt of the Low Countries forms a remarkable exception. It is the westernmost region settled by Linearbandkeramik (LBK) communities and their cousins of the Groupe de Blicquy (BQY) during the late $6^{\text {th }}$ and early $5^{\text {th }}$ millennium calBC. With the sudden disappearance of these communities, however, the Neolithic as a whole seems to have vanished as well. The region was not occupied by Hinkelstein/ Grossgartach and Roessen, the post-LBK Danubian cultures that can be found to the east and south, nor by a local Neolithic similar to the Cerny in Northern France. Only during the last centuries of the $5^{\text {th }}$ millennium calBC, at the beginning of the 'Michelsberg Culture phase', does the Neolithic take up its thread (Fig. 1).

The existence of such hiatus is of importance for understanding the regional transition process, and implicitly also for understanding the relationship between local hunter-gatherers and the incoming Neolithic in general. This paper focuses on the gap and the explanation of its existence. After presenting the archaeological cultural sequence in the region, the relationship of the Neolithic with local non-Neolithic communities is explored. This is done by analysing the indications of contact on the one hand and the nature of the Neolithic compared to the local Mesolithic on the other. 


\section{The Neolithisation process in the southern part of the Low Countries}

The local Mesolithic during the late $6^{\text {th }}$ millennium calBC remains poorly understood. This is due to a general decrease in the number of sites and to problems with the taphonomy and post-depositional formation of the archaeological record. In the Low Countries, many Mesolithic sites are known as surface sites from the coversand region in Northern Belgium and the Netherlands. These sites are often palimpsests and even if they are excavated, their absolute dating is confronted with major problems. Bad or doubtful spatial associations between dated samples and archaeological assemblages, dislocation of artefacts and samples caused by bioturbation, and problems related to the nature of samples are frequently mentioned obstructing factors (see Crombé 1999; Schild 1998; Vermeersch 2006). Crombé et al. (1999) claim that dates obtained on hazelnut shells are more reliable than those on charcoal samples, but even short-lived samples do not escape the palimpsest and bioturbation problems. As a consequence and in contrast to the Rhine/Meuse river delta (Louwe Kooijmans 2003), there are no well characterised and well dated sites that can be used as a reference to relatively date the later Mesolithic.

The most diagnostic elements of the Late Mesolithic lithic industry, i.e. from the mid 7 th millennium cal$\mathrm{BC}$ onwards, are the production of regular blades in so-called Montbani style and the appearance of trapezes. Due to the problematic dating of the assemblages, a detailed and reliable regional typochronology is not available. Rhombic and wide, rectangular trapezes are generally regarded as late $(e . g$. Vermeersch et al. 1992) and are followed by asymmetric points with flat inverse retouch and LBK-like points. The Late Mesolithic in the wetland area and its successors of the Swifterbant from the early $5^{\text {th }}$

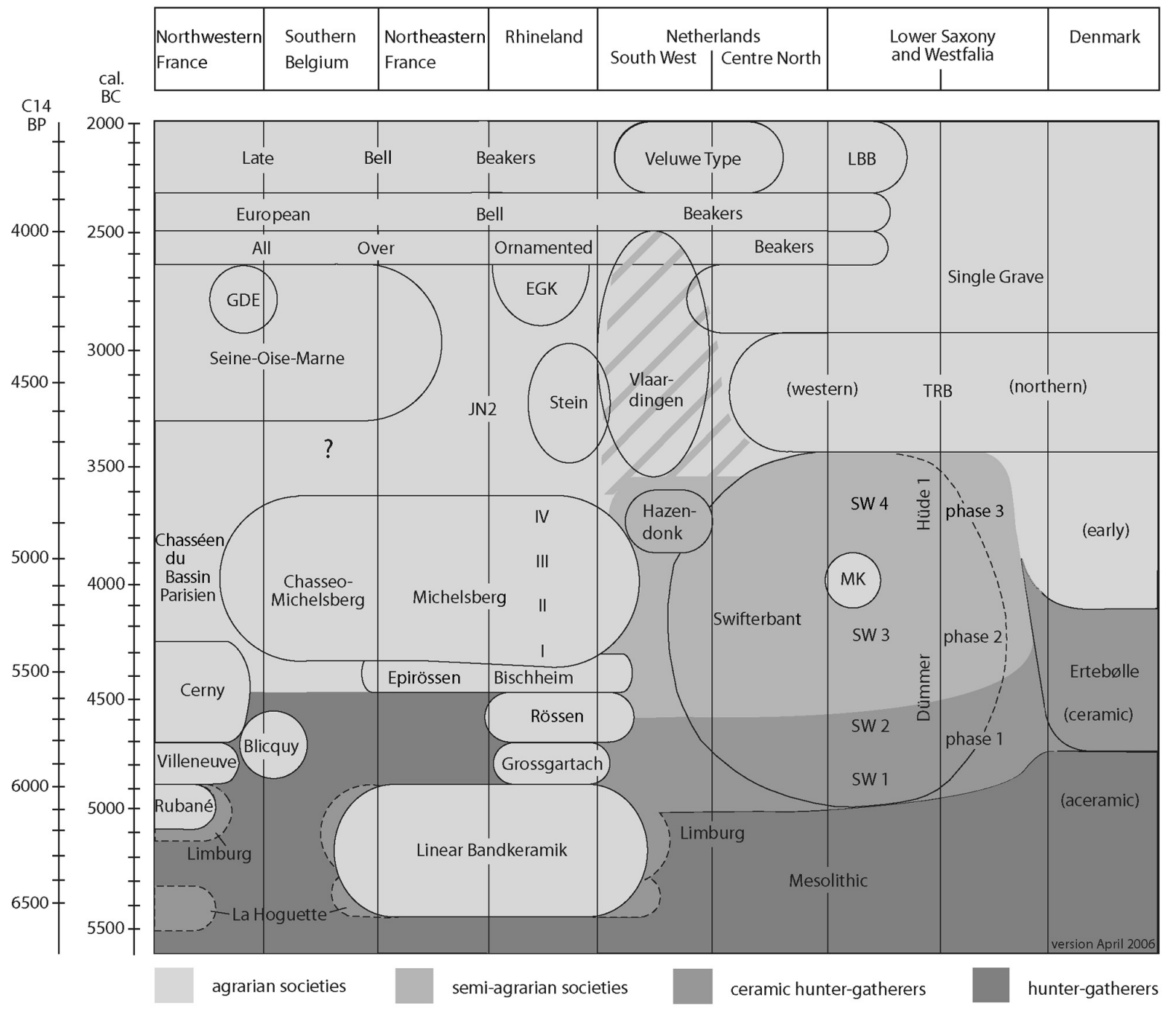

Fig. 1. The Neolithic sequence in the Lower Rhine Area and adjacent areas (Louwe Kooijmans 2006.Fig. 27.15). 
millennium onwards, on the other hand, have a lithic industry characterised by more flake-based production and the presence of small and irregular symmetric trapezes (e.g. Crombé et al. 2005; Peeters et al. 2001; Van Gijn et al. 2001b).

A growing number of observations are claimed to indicate the introduction in Northwest Europe of elements conventionally linked with the Neolithic, like cereal cultivation, cattle herding and the production of pottery, prior to the arrival of the first archaeologically visible Neolithic culture (e.g. Jeunesse 2003; Richard 2004). These indications should not be ignored and need to be integrated in the debate as a working hypothesis. To date, however, the 'indices précoces' remain extremely contentious (see Behre 2007) and cannot yet change the traditional idea that the Neolithic started with the arrival of Linearbandkeramik (LBK) communities.

The same is true for the Low Countries where, moreover, no 'initial indications' have yet been claimed. The LBK arrived in this region around 5300 calBC and has predominantly been regarded as intrusive and the result of demic migration to the region (e.g. Bogucki and Grygiel 1993; Louwe Kooijmans in press). Their relationship with possible local hunter-gatherer communities remains unclear. After an occupation of some centuries, the LBK communities suddenly disappeared from the stage. The reason for their disappearance is unknown. Possibly, the westernmost territories in Hainaut and Hesbaye had become a marginal area for the LBK communities in crisis (Jadin 2003.714-15 referring to unpublished hypotheses of Zimmerman and Stehli; Modderman 1988). In any case, in their western settlement territories they are replaced by the Groupe de Blicquy/Villeneuve-Saint-Germain (BQY/VSG). Differences with the LBK as a whole can be noted mainly in stylistic issues. Archaeological remains relating to the settlement system, material culture and palaeo-economy are remarkably similar. Although its chronological position with respect to LBK is still debated (cf. Constantin 2000; Jeunesse 1998b), BQY/VSG can be seen as related to LBK in many ways. Current views imply it to have developed from the recent and final LBK in the Paris basin (RRBP and RFBP), probably contemporary with the final LBK in the Hesbaye region $(\mathrm{Ja}-$ din 2003.715). Like the LBK, the BQY/VSG communities suddenly disappear, this time leaving the region more or less empty.

Whether hunter-gatherers continued to be active in the sandy lowlands during and after the LBK/BQY occupation is uncertain, due to the above-mentioned dating problems. Very few Late Mesolithic sites have been dated beyond the 5300 calBC LBK arrival date, and the few dates that are available are often contested (see Crombé et al. 2005). Arts (1989) stresses the absence of radiocarbon or typological evidence for the prolongation of the Mesolithic after the LBK occupation. He suggests that the region was virtually uninhabited during most of the $5^{\text {th }}$ millennium calBC. In a recent paper, Shennan and Edinborough (2007) claim more or less the same thing for Germany and Poland. These authors use summed probability distributions of radiocarbon dates as a proxy for population density. Both the German and Polish datasets are characterised by a severe drop in the number of radiocarbon dates after the LBK occupation and prior to the end of the $5^{\text {th }}$ millennium or even the middle of the $4^{\text {th }}$ millennium calBC. The same exercise for the dates of the Low Countries would clearly result in a similar image. From their assumption of probability distributions as a proxy for population densities, this leads to the conclusion of a dramatic population crash after the LBK occupation. The reason for this population crash is unclear; conflict and climatic changes are invoked as possible intervening factors (ibid.).

For the southern part of the Low Countries, at least, the lack of dates from the middle $5^{\text {th }}$ millennium cal$\mathrm{BC}$ does, however, not prove the absence of occupation or even a much lower population density. Shennan and Edinborough (ibid.) rightly mention the problem of comparability between Mesolithic and Neolithic dates. They minimise this critique by claiming that the differences in estimated population densities are too great to be explained by an underrepresentation of Mesolithic dates, and that Mesolithic sites are not smaller or more difficult to discover than early Neolithic ones. The latter fact is deduced from the existence of, for instance, often large and extremely visible Mesolithic shell middens, and the assumption that the more mobile Mesolithic settlement system will have resulted in actually more occupation sites (ibid.). These arguments are, however, not apt to lead to a safety in numbers. It is clear that there is a fundamental problem of identifying, excavating and reliably radiocarbon dating late hunter-gatherer sites in general and in a coversand landscape in particular (e.g. Crombé et al. 1999; Schild 1998; Vermeersch 2006). At the same time, LBK settlement sites are generally scattered with features such as pits and postholes, often containing datable material. They are therefore particularly suitable for obtaining large numbers of radiocarbon dates. More- 
over, in comparison to Late and Final Mesolithic sites or even those dating from the Michelsberg/Chasséen horizon, LBK site phases can be more easily distinguished on the basis of pottery seriations. LBK sites are thus more liable to be the object of specific radiocarbon dating programs (e.g. Jadin and Cahen $2003 a$ ), resulting in a clear over-representation of these sites. It may be doubted that taking into account only a single date per site phase (Shennan and Edinborough ibid.) solves the problem.

The existence of a yet archaeologically invisible local component should therefore still be considered. The exact position of La Hoguette and Limburg Pottery in this story is not yet clear, despite the fact that in the literature both elements are progressively regarded as pottery produced by hunter-gatherer groups that adopted certain agro-pastoral elements in their economy (e.g. Gronenborn 2003; Jeunesse 2002; Zvelebil 2004).

The Neolithic seems to have taken up its thread only several centuries later, by the end of the $5^{\text {th }}$ millennium calBC. This 'second' Neolithic, belonging to the Chasséen/Michelsberg Culture phase clearly differs from that of the Danubian cultures. Several hypotheses have been raised on its origin: coming from the West (Jeunesse 1998a; Jeunesse et al. 2002/2003; Scollar 1959), from the East/Rhineland (Lüning 1967), from the North, i.e. rooted in the TRB culture (Lichardus 1976) or having a polycentric origin (Dubouloz 1998; Schier 1993; Vanmontfort 2004). ${ }^{1}$ Ideas have been raised on the possibility of huntinggathering communities having been active in the region during this phase (Verhart 2000.115, 231; Vermeersch 1990). Nevertheless, this phase is traditionally assumed to represent the ultimate Neolithisation of the loess belt and the adjacent coversand region.

The chronological hiatus in the sequence of the Neolithic in the Southern Low Countries between approximately 4850 and 4300 calBC, together with the fundamental difference between the late $6^{\text {th }}$ and late $5^{\text {th }}$ millennium calBC Neolithic makes this region particularly interesting. The question of where the people wearing the 'Michelsberg Culture' outfit came from is more topical than elsewhere. Was the region indeed practically void of human occupation during the $1 / 2$ millennium hiatus, or was it occupied by a population not visible archaeologically? If the latter was the case, the question arises as to what the re- lationship was between this native population and the local variant of the Chasséen and Michelsberg Cultures. Two keys are needed to answer these questions: hunter-gatherer activity in and beyond the loess region prior to, during and possibly after LBK arrival, and evidence for interaction between native hunter-gatherers on the one hand and farmers of the different Neolithic traditions on the other.

\section{Contact and interaction during the 'Early Neo- lithic' LBK/BQY phase (5300-3850 calBC)}

It is currently assumed that the spread of the LBK from Central Europe was a combination of demic movement and acculturation processes (see Gronenborn 1999; Gronenborn 2003; Price et al. 2001; Zvelebil 2000; Zvelebil 2004). For the Low Countries, however, all available evidence still suggests that their introduction was principally the result of a demic movement perhaps, with a progressive integration of native populations. Arguments in favour of this hypothesis focus on the large contrast between LBK and the late Mesolithic as currently understood (e.g. Louwe Kooijmans in press): transitional complexes are inexistent; material culture, subsistence and mobility are quite different from those of the native Late Mesolithic populations, and raw material procurement strategies differ considerably (see Allard 2005; Van Assche 2006).

It can be assumed that native populations were present in the area at the time of LBK arrival. According to several authors, these may even have known a pre-LBK first Neolithisation stage (Gronenborn 2003; Jeunesse 2000; Zvelebil 2000) but, unfortunately, they remain largely invisible (see above). Awaiting new sites and dates proving the presence of other groups during the late $6^{\text {th }}$ and $5^{\text {th }}$ millennium cal$\mathrm{BC}$, they can best be identified indirectly. Contacts and exchanges between LBK and native populations should indeed be reflected in the archaeological record, both on Neolithic sites and beyond.

\section{Patterns and contact finds}

In a forthcoming paper, a new method is elaborated to map the hunter-gatherer activity on the loess belt and beyond (Vanmontfort forthcoming). Rather than focusing on well dated and excavated sites, which are absent anyhow, individual microliths were plotted and used as a proxy for changes in the human presence during the entire Mesolithic period. This analysis confirmed that hunter-gatherers ventured

1 For a discussion on the origins of the Michelsberg Culture see Jeunesse et al. 2002/2003. 
on the loamy soils from the Pre-boreal phase onwards and that changes in exploitation could be identified by plotting the individual microliths. Several remarkable patterns resulted from the analysis. The LBK apparently settled in areas only marginally exploited by hunter-gatherers. Hunter-gatherer activity was not at all attracted to the regions where LBK communities had settled (Fig. 2). If anything, they seem to have retracted their activity to areas further away from the LBK settlement clusters. These patterns confirm the important differences between the LBK people and the local hunter-gatherers and as such can be regarded as an extra argument for the demic influx hypothesis of LBK dispersal.

Contact finds can bring us on the track of possible interactions between immigrating LBK and native populations. Assuming that native populations during this phase resemble their Mesolithic ancestors, this would be visible in Mesolithic type artefacts in Neolithic contexts or vice versa. Mesolithic artefacts in LBK context are, however, very scarce. Some microliths have been found in LBK pits, but it is unli- kely that they actually represent contact and exchange. Only few of them are known and they also include Middle Mesolithic microlith types that are assumed to have been out of use since the middle of the $7^{\text {th }}$ millennium calBC. They are more likely to be residual (e.g. Allard 2005.237; Jadin and Cahen 2003b; Van Assche 2005). Another element on LBK sites that relates to Mesolithic traditions is the use of Wommersom quartzite and Phtanite. Both were favoured raw materials during the Mesolithic (Caspar 1984b). However, Wommersom has only rarely been found in LBK contexts, for instance close by its source location on the LBK sites of the Kleine Gete cluster (Lodewijckx and Bakels 2000) and in some of the Hesbaye sites (Jadin and Cahen 2003b.237). In the latter case, the Wommersom artefacts are either undiagnostic or typically Mesolithic. Like the Mesolithic microliths, the most likely hypothesis is that they are residual remains of previous Mesolithic occupations (ibid.). None of the Wommersom artefacts from the Kleine Gete sites can with certainty be attributed to the Mesolithic or LBK (Lodewijckx and Bakels 2000). It therefore remains questionable

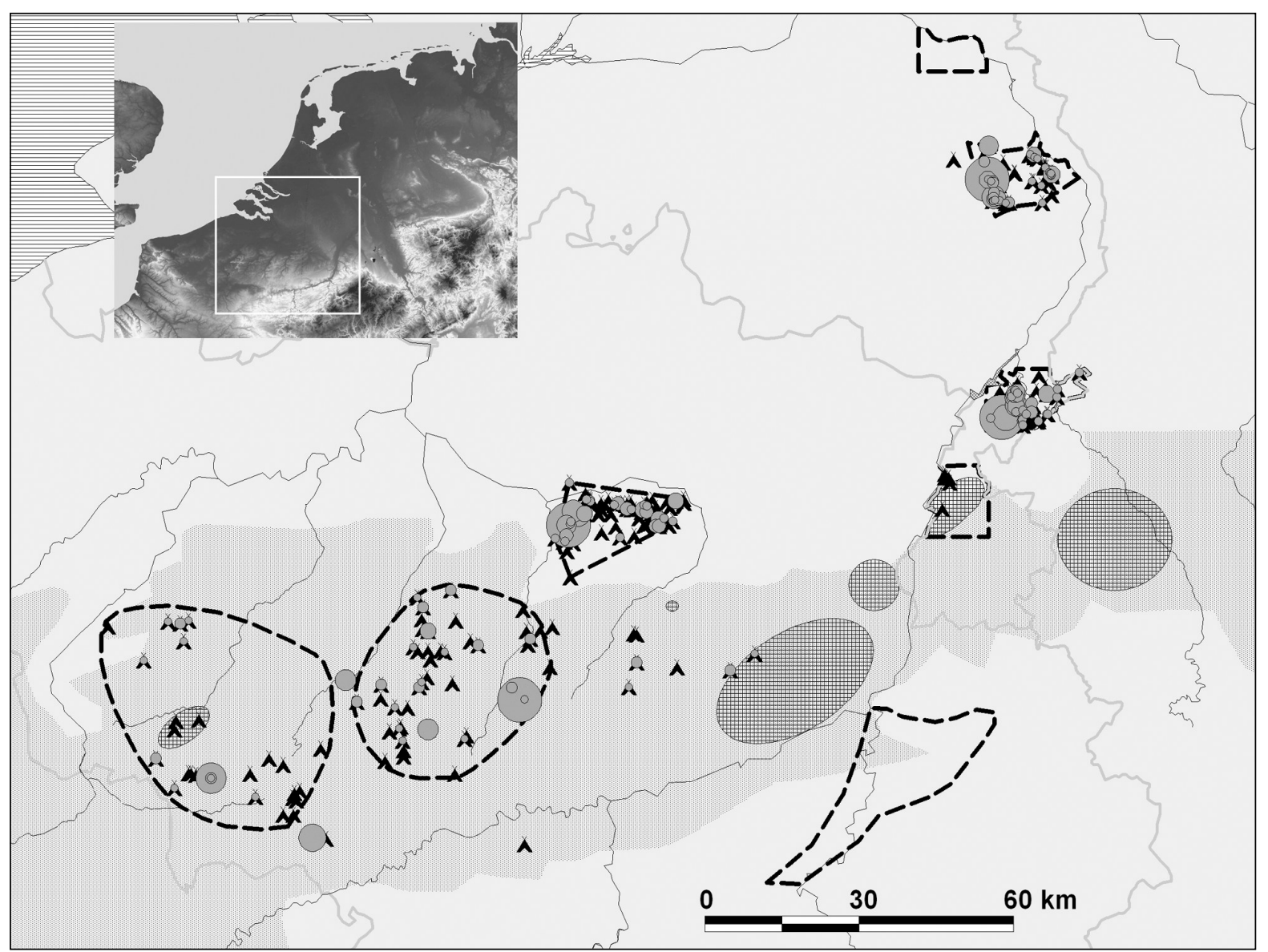

Fig. 2. Spatial distribution of microliths and LBK settlement territory. The loess belt region is shaded. Tents represent microlith find spots, circles show the number of trapezes (1/2/>3). Hatched regions correspond to $\mathrm{LBK}$ settlement territories (after Vanmontfort forthcoming). 
if they are actually part of the LBK stone tool production. Even if they are, however, the role of indigenous populations in their acquisition and use remains purely hypothetical. Phtanite was frequently used for the production of LBK adzes, and unfinished fragments are known from several LBK sites in Hesbaye and the Kleine Gete region, all over $30 \mathrm{~km}$ from its source (Caspar 1984a). No additional information is known on how the LBK people acquired the raw material for their adzes. The involvement of Mesolithic communities in the LBK acquisition also remains purely hypothetical.

Evidence for contact in a 'Mesolithic' context is also generally contentious. LBK arrowheads, pottery fragments and adzes are frequently found beyond LBK settlement territory, including on Mesolithic sites. Their association with Mesolithic artefacts is, however, always uncertain. Most Late Mesolithic sites are known only by surface scatters, while none of the excavated sites yielded Mesolithic features containing reliably associated Neolithic artefacts. The Neolithic artefacts found together with the Mesolithic ones can also be explained by assuming the sites to be palimpsests and including both a Mesolithic and Neolithic occupation phase. This reasoning is confirmed by the presence of LBK artefacts on Early and Middle, as well as on Late Mesolithic sites (Van Assche 2006). Spatially, LBK artefacts beyond LBK settlement territory concentrate on the loess belt and a northern frontier zone of approximately $30 \mathrm{~km}$. These artefacts may also have been remains of LBK expeditions in search for raw materials or pasture lands to herd their cattle (e.g. Bakels 1978; Jeunesse 2000; Verhart 2000.37). The flint procurement site at Banholt (Brounen and Peeters 2001) and the ephemeral site at Echt-Annendaal (Brounen 1985) are examples of such LBK excursions. On the other hand, there are at least some indications for contact and exchange. As Verhart (2000.37; 2003) rightly stresses, the LBK artefacts found further from LBK settlement territory are unlikely to be the result of excursions of LBK communities. In this case, more ephemeral LBK or Roessen sites would be expected in the intermediate region. Rather, they would represent theft or the exchange of LBK objects by native populations. A similar exchange system is in place during the subsequent Rössen phase (ibid.). The presence of an LBK arrowhead and BQY pottery in the Swifterbant contexts of Hardinxveld-Giessendam (Raemaekers 2001; Van Gijn et al. 2001a) are other indications of contact and the movement of objects during the late $6^{\text {th }}$ and early $5^{\text {th }}$ millennium calBC. The precise exchange systems, however, remain unidentified.

\section{Discussion}

Summing things up, there are at least some indications for interaction and exchange between native hunter-gatherer groups and LBK/BQY communities. Nevertheless, the identification of particular objects as the result of exchange remains difficult. Most Mesolithic sites are simply not suitable for identifying such contacts. The absence of evidence therefore should not surprise us and certainly does not equal the evidence of absence. This leaves two explanations for the nature of the data: either the archaeological hiatus actually corresponds to an absence of native populations from 5500 calBC onwards beyond the wetland Swifterbant territory, or those populations were present, but are not archaeologically visible. The first hypothesis implies a subsistence change that triggered the retraction of hunter-gatherer occupation into the wetland regions during the early $6^{\text {th }}$ millennium calBC. From that moment onwards, the sandy and loamy uplands are at most marginally exploited in a wider exploitation system from the wetlands. This hypothesis seems hard to match with the numerous LBK adzes and Roessener Breitkeile scattered over the coversand region to more than $200 \mathrm{~km}$ from the nearest known LBK or Roessen settlement. Moreover, it does not fit with the mutual exclusion of LBK settlement territory and 'native' exploitation of the loess belt as shown on the basis of microlith distribution. This exclusion actually implies the active presence of native groups at the time of LBK arrival. The second hypothesis is more likely. It assumes that native populations are nearly invisible archaeologically due to their undiagnostic toolkit or taphonomical reasons. They are visible indirectly, through the LBK adzes and Roessener Breitkeile in the western part of the North European Plain, acquired by these populations and perhaps exchanged among them. The invisibility of their proper sites is related to dating problems (see above). Some of the already identified and/or excavated sites could have been contemporaneous with or even posterior to the LBK/BQY occupation, but they can hardly be, or not be separated at all from older Late Mesolithic sites. The only possible diagnostic element is the evolved arrowhead with flat inverse basal retouch (RIP). Unfortunately, its appearance is not exactly dated and could also predate the LBK arrival. Alternatively, the invisibility could be the result of a shift in material culture and site location choice, hampering the identification of the local Mesolithic's successors. The contemporaneous Swifterbant culture toolkit (e.g. Peeters et al. 2001; Raemaekers 1999; Van Gijn et al. 2001a; Van Gijn et al. 2001b), for example, is also hardly 
diagnostic. It is unlikely that such a toolkit would be identified in open-air sites on the uplands, regardless of the possibility for settlement location continuity from the earlier Late Mesolithic onwards. Due to the absence of data, the material culture of these populations and their subsistence can only be guessed. The paradox of practically no unquestionable indications for contact, but nonetheless the assumption that native populations must have occupied at least parts of the Low Countries' sandy and loamy uplands during and perhaps also after LBK/BQY occupation can be explained in different ways. It can be regarded as an indication of the limited exchange between the two groups, suggesting that they avoided contact (Keeley 1992). On the other hand, clear associations of imperishable exchange objects and 'Mesolithic' settlement debris should be presumed to be rare, due to the value doubtlessly ascribed to those items. Moreover, due to the nature of the sites, the association of items and dating samples will always be contentious.

Despite the indications of contemporaneity and interaction, the data confirm the difference between hun- ter-gatherers and LBK. There is no data supporting the idea of symbiosis.

\section{Contact and interaction during the 'Middle Neo- lithic' Chasséen/Michelsberg Culture phase (4300-3800 calBC)}

\section{Michelsberg Culture?}

The second Neolithic phase in the Low Countries is clearly different from the first 'Danubian' one in almost all its archaeological aspects. During this phase, settlement sites are not restricted to Siedlungskammer, but have a much wider distribution. The entire loess belt is fairly homogeneously covered with sites, including enclosure sites and flint mines as central foci (Fig. 3). The lack of large dwelling structures with deeply planted posts signals a more mobile settlement system. At several sites in this region thousands of artefacts are scattered over a surface of many tens of hectares. This is in clear contrast with the coversand region, for which only small and often undiagnostic surface scatters are typical, and where no enclosure sites have been identified thus far. These regions were thus differently exploited and perhaps

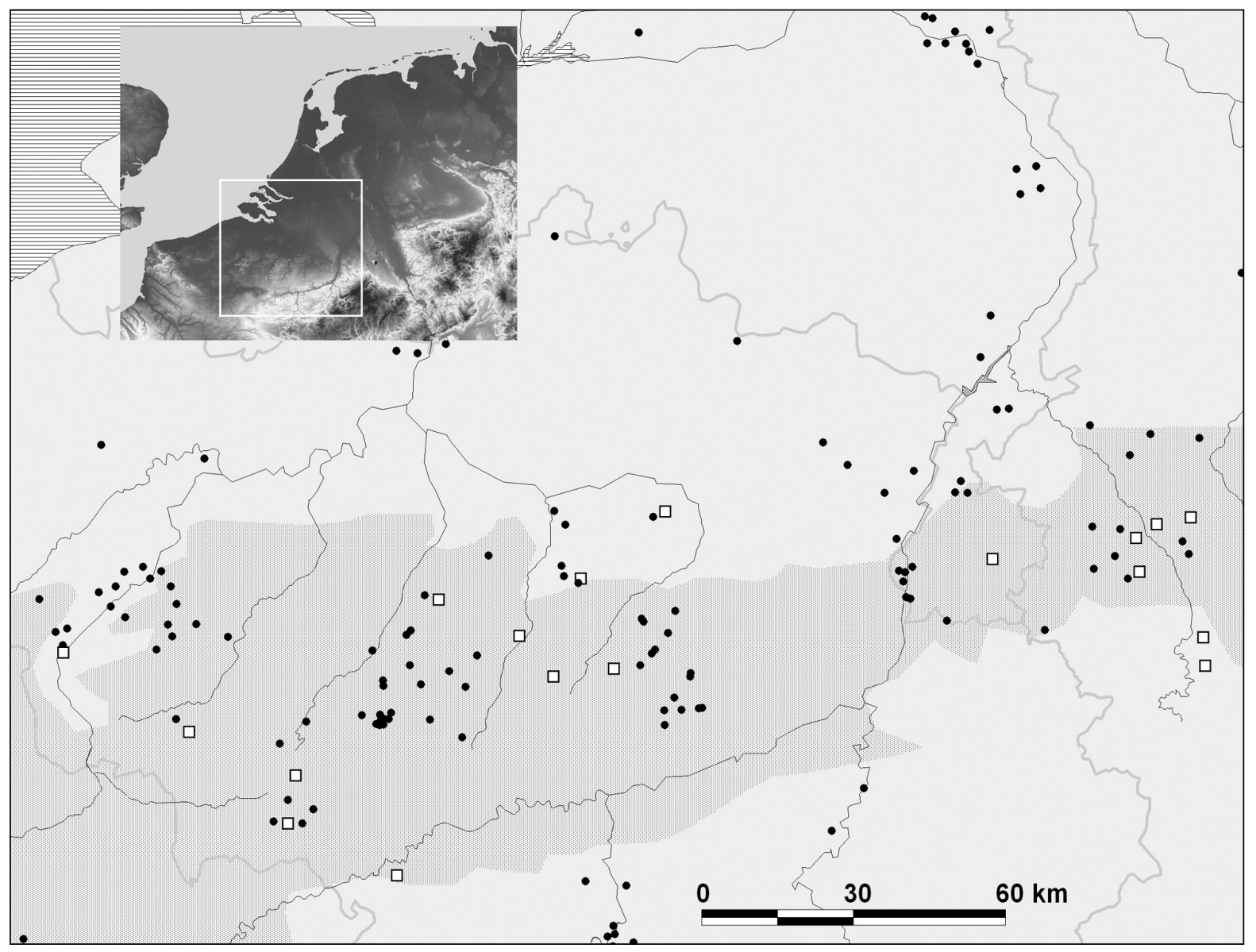

Fig. 3. Spatial distribution of sites and finds from the late $5^{\text {th }}$ and early $4^{\text {th }}$ millennium calBC. Enclosure sites are represented by squares (after Vanmontfort 2004). 
part of a different settlement system (Vanmontfort 2004.329-332). The hierarchised settlement pattern, with enclosure sites, flint extraction and exploitation sites, as well as the scarcity or even absence of dwelling structures and other constructions, fits well with the wider Northwest European Neolithic of the late $5^{\text {th }}$ and early $4^{\text {th }}$ millennium calBC.

Fundamental differences from the preceding Neolithic phase can also be noted in the material culture, i.e. the lithic and pottery industry. The flint industry is no longer dominated by blade production. Instead, a generally dominant, expedient, flake-based common tool production can be distinguished from the specialised production of standardised tools. The latter tools include the flint axes and large blades, produced in and imported from the flint exploitation sites. This fits with the contemporaneous Neolithic lithic tool production traditions in the rest of Northwest Europe. The toolkit in the Scheldt basin occupies an intermediate position between the Chasséen and Michelsberg Culture traditions. Arrowheads are dominated by leaf-shaped examples as in the Rhineland Michelsberger Kultur. Flake axes, on the other hand, are a typical element and rather link it with the Northern French traditions of Cerny and Chasséen septentrional.

The pottery is basically undecorated and characterised by a more varied range of shapes than the LBK/ BQY pottery traditions. Instead of bone and grog, grit becomes the most frequently used tempering material. On a more detailed level, the lack of correspondence with Rhineland Michelsberg Culture pottery is apparent. Technical characteristics as well as morphology and the rare decoration (Fig. 4) fit much better with the Northern French Bischheim (Epi-Roessen) and Chasséen traditions (Vanmontfort 2004; Vanmontfort et al. 2001/2002). It may even be questioned to what extent the label Michelsberg Culture is appropriate for the Scheldt basin sites. Rather, these different pottery traditions - probably even including the Rhineland Michelsberg Culture - seem rooted in the Northern French post-Roessen (Vanmontfort 2001; 2006).
As for absolute dating, the origin of Chasséen septentrional, Bischheim occidental, Michelsberger Kultur, as well as the Scheldt basin sites can be placed after around 4300 calBC (Vanmontfort 2004). Unfortunately, due to a plateau in the calibration curve, between approximately 4300 and $4050 \mathrm{calBC}$, it can not be specified.

The Northwest European archaeological cultures of the late $5^{\text {th }}$ and early $4^{\text {th }}$ millennium in their polythetic meaning ( $c f$. Clarke 1968) thus seem polycentrically formed and developed. The 'Belgian Michelsberg Culture', as it is still frequently labelled, is in this view a local version of similar developments in neighbouring regions.

\section{Evidence for forager-farmer contact}

Ideas have been raised about the existence of pure, Late Mesolithic hunter-gatherers during this Neolithic phase (Verhart 2000.115 \& 231; Vermeersch 1990). No uncontested radiocarbon dates confirm this (see above), however, and examples for exchange are extremely scarce and contentious. The few Mesolithic 
artefacts in late $5^{\text {th }}$ or early $4^{\text {th }}$ millennium features could also be residual of an earlier occupation. For Middle Neolithic artefacts in Mesolithic context, similar reasoning can be followed, quite like most Danubian artefacts in such contexts (see above). A frequently cited association is that of the Late Mesolithic site at Dilsen-Dilserheide III (Luypaert et al. 1993), where sherds of a Neolithic vessel were found both vertically and horizontally interstratified within the Late Mesolithic artefact scatter. No other diagnostic Neolithic artefacts were found in the same context. The two arrowheads and three flakes of polished flint axes that were found within the plough layer cannot be dated securely enough. Still, this site is the only such example. Until more finds confirm the possibility of such associations, this situation should be regarded as a palimpsest of a Late Mesolithic site and a still unspecified Neolithic passage.

\section{Discussion}

A local development or transcription implies the input of a local component. Such a local component is, unfortunately, invisible archaeologically. The only candidates are successors of the local Mesolithic. Their archaeological invisibility should not surprise us. The number of excavated and dated contexts is, anyhow, small, and if we accept the presence of a local component to have been nearly invisible during LBK/BQY occupation (see above), then their continuation into the 4850-4300 phase can also be expected. Moreover, there are other arguments in favour of a Mesolithic-Middle Neolithic connection. In its contrast with the Danubian culture traditions, the settlement pattern and certain aspects of material culture during this phase in the Scheldt basin indeed link up with the Late and Final Mesolithic traditions.

The more mobile settlement pattern and the distribution of settlement sites all over the loamy but also sandy uplands are examples of such connection. The use of the same site locations is another. The combined presence on sites of Mesolithic and Middle Neolithic artefacts have in the past led to hypotheses of 'secondary Neolithic cultures' (De Laet 1958.89 ff) and 'Neolithising Mesolithic' (Vermeersch 1976.237 $f f)$. These interpretations fully or partially ignored the possibility of palimpsests, but they are symptomatic of the continued use of locations.

Continuity has also been claimed for the Mesolithic and Middle Neolithic burial practices in Southern Belgium (Cauwe 1998). A recent radiocarbon dating program confirmed the existence of both Mesolithic and Neolithic burials (Cauwe et al. 2000; Toussaint
2002). A major counter argument against continuity is the existence of a chronological hiatus in the radiocarbon date sequence between the Early Mesolithic and Middle Neolithic period. Despite the presence of Mesolithic camps in the region between 8000/7600 and $6000 / 5700 \mathrm{calBC}$, there is only a single burial context known for the period between the early $8^{\text {th }}$ millennium calBC and approximately 4300/4050 calBC (see Toussaint 2002). On the other hand, the disappearing of dated burial contexts nicely corresponds to a change in the exploitation of the region. From 8000/7800 calBC onwards, at least the Ourthe Basin no longer functioned as a residential centre, but only as a logistically exploited region (see Henrard 2003; Vanmontfort forthcoming). In this sense, the disappearance of burial contexts is a result of a change in the exploitation rather than a change in burial practices, as has been claimed by Toussaint (2002).

Lastly, Verhart (2000.231) identified a number of Mesolithic traits in the Chasséen/Michelsberg flint industry. Besides the similar use and processing techniques of the flint tools and similarities in certain tool types, both industries are characterised by a distinction between good quality imports and an expedient production on locally available flint of often inferior quality (ibid.).

\section{Modelling the transition}

The data presented in this paper show that the Mesolithic-Neolithic transition in the southern part of the Low Countries took a long time to complete and there appears to have been a mosaic of processes involved. Making abstraction of the contentious initial indications for a pre-LBK introduction of Neolithic elements, it all seems to have started around 5300 calBC when the first LBK communities came leapfrogging into the area. Possibly these colonists integrated native people in their settlements, but in general the data suggest the at least short-term survival of native hunter-gatherer populations in a mutual conflict-avoiding atmosphere. At least for this region, this challenges the interaction models based on mutual benefit (Bogucki 1988; Gregg 1988). These models assume the attraction of hunter-gatherer activity to the farmer settlements. It also challenges the idea of a complete assimilation or expulsion of native populations and the 'actively hostile' conflict model as proposed by Keeley (1992) for this region. In the latter model, more direct indications for conflict would be expected, for instance by a concentration of Mesolithic arrowheads near LBK settle- 
ment clusters. Nevertheless, there are some indications for exchange of at least prestigious items, and it is possible that these interactions also resulted in the movement of people across the frontier. All this fits best with the open stationary frontier zone as defined by Dennell (1985) and Zvelebil (1998). The entire period corresponds to the availability phase (sensu Zvelebil 1986; Zvelebil and Rowley-Conwy 1984).

The sudden disappearance of LBK and BQY cannot be explained, but it is clear that their relatively short stay in the area will have left its mark. What happened next is, unfortunately, still invisible archaeologically, and can only be deduced from the image at the end of the $5^{\text {th }}$ millennium calBC. The region is likely to have been the scene for, possibly several and interacting, still unidentified populations that take up different positions on the continuum between the Mesolithic and Neolithic. In any case, these seem to have played an important role in the formation of the local Chasséen/Michelsberg Culture that is confirmed to be at least as much rooted in the Mesolithic than in the Danubian Neolithic. The processes responsible for the formation of this 'second' Neolithic and its precise timing remain unidentified. The result of these processes only becomes archaeologically visible once pits and enclosures are constructed and operate as traps for archaeological and datable remains. It remains impossible to determine what proportion of this period corresponds to the substitution phase and whether the consolidation phase only began around 4300 calBC.

\section{Conclusion}

A chronological gap between the early and late $5^{\text {th }}$ millennium calBC is present in the Neolithic sequence in the southern part of the Low Countries. This gap can at present only be bridged indirectly, by a detailed analysis of the situation prior to and after the gap. A start to such analysis has been made in this paper. The first results show the transition process in this region to be more than a simple and unidirectional 'Neolithisation'. Several of the many Mesolithic-Neolithic transition models that have been put forward in the past can explain parts of the entire process. The working hypothesis proposed here encompasses the leapfrogging arrival of LBK, contacts and exchanges with native populations and their gradual transition to a Neolithic way of life quite different from that of the Danubian settlers. Future discoveries should be able to show the existence of transitional phases but, unfortunately, the taphonomy of both loamy and sandy uplands will always make it hard to obtain good quality data. The most informative data can be expected from the wetlands in the region.

\section{ACKNOWLEDGEMENTS}

The research for this paper is funded by NWO (Netherlands Organisation for Scientific Research) within the framework of the Leiden University "From Hardinxveld to Noordhoorn: From Forager to Farmer' project.

\section{REFERENCES}

ALLARD P. 2005. L'industrie lithique des populations rubanées du Nord-Est de la France et de la Belgique. Internationale Archäologie 86. Marie Leidorf GmbH. Rahden.

ARTS N. 1989. Archaeology, environment and the social evolution of later band societies in a lowland area. In C. Bonsall (ed.), The Mesolithic in Europe. Papers presented at the third international symposium edinburgh 1985. John Donald. Edinburgh: 291-312.

BAKELS C. C. 1978. Four Linearbandkeramik settlements and their environment: A paleoecological study of Sittard, Stein, Elsloo and Hienheim. Analecta Praehistorica Leidensia 11. Leiden.
BEHRE K.-E. 2007. Evidence for Mesolithic agriculture in and around Central Europe? Vegetation History and Archaeobotany 16: 203-219.

BOGUCKI P. I. 1988. Forest farmers and stockherders. Early agriculture and its consequences in Northcentral Europe. Cambridge.

BOGUCKI P. I., GRYGIEL R. 1993. The First Farmers of Central Europe: a Survey Article. Journal of Field Archaeology 20: 399-426.

BROUNEN F. T. S. 1985. HVR 183, vroeg-, midden- en laatneolithische vondsten te Echt-Annendaal. Archeologie in Limburg 24: 66-71. 
BROUNEN F. T. S., PEETERS H. 2001. Vroeg-neolithische vuursteenwinning en -bewerking in de Banholtergrubbe (Banholt, gem. Margraten). Archeologie 10: 133-149.

CASPAR J.P. 1984a. Fabrication et réaménagement d'herminettes rubanées en phtanite. Bulletin de la Société royale belge d'Anthropologie et de Préhistoire 95: 47-58.

1984b. Matériaux lithiques de la préhistoire. In D. Cahen, P. Haesaerts (eds.), Peuples chasseurs de la Belgique préhistorique dans leur cadre naturel. Bruxelles: 107-114.

CAUWE N. 1998. Confrontation des espaces funéraires mésolithiques et néolithiques. Anthropologie et Préhistoire 109: 141-153.

CAUWE N., POLET C., ORBAN R. 2000. Nouvelles datations d'ensembles funéraires du Néolithique moyen du sud de la Belgique. Internéo 3: 29-35.

CLARKE D. L. 1968. Analytical Archaeology. Methuen \& Co. London.

CONSTANTIN C. 2000. À propos d'un article de Christian Jeunesse paru dans le Bulletin de la Société Préhistorique Luxembourgeoise (Jeunesse, 2001). Bulletin de la Société Préhistorique Luxembourgeoise 22 (2002): 117-126.

CROMBÉ P. 1999. Vers une nouvelle chronologie absolue pour le Mésolithique en Belgique. In A. Thévenin (ed.), L'Europe des derniers chasseurs Épipaléolithique et Mésolithique. Peuplement et paléoenvironnement de I'Épipaléolithique et du Mésolithique. Paris: 189-199.

CROMBÉ P., GROENENDIJK H., VAN STRYDONCK M. 1999. Dating the Mesolithic of the Low Countries: some practical considerations. In J. Evin, C. Oberlin, J. P. Daugas, J. F. Salles (eds.), ${ }^{14} \mathrm{C}$ et Archéologie. Actes du 3ème congres international (Lyon, 6-10/04/1998). Mémoires de la Société Préhistorique Française, Tome XXVI (Supplément de la Revue d'Archéométrie): 57-63.

CROMBÉ P., PERDAEN Y., SERGANT J. 2005. La néolithisation de la Belgique : quelques réflexions. In G. Marchand, A. Tresset (eds.), Unité et diversité des processus de néolithisation sur la façade atlantique de l'Europe (6e - 4e millénaires avant J.-C.), Table ronde de Nantes, 26-27 Avril 2002. Mémoire de la Société Préhistorique Française 36. Paris: 47-66.

DE LAET S. J. 1958. The Low Countries. Ancient Peoples and Places 5. Thames and Hudson. London.

DENNELL R. W. 1985. The Hunter-Gatherer/Agricultural Frontier in Prehistoric Temperate Europe. In S. W. Green, S. M. Perlman (eds.), The Archaeology of Frontiers and Boundaries. Academic Press. Orlando: 113-136.
DUBOULOZ J. 1998. Réflections sur le Michelsberg ancien en Bassin parisien. In J. Biel, H. Schlichtherle, M. Strobel, A. Zeeb (eds.), Die Michelsberger Kultur und ihre Randgebiete. Probleme der Entstehung, Chronologie und des Siedlungswesens (Kolloquium Hemmenhofen, 21-23 Feb 1997). Materialhefte zur Archäologie in Baden-Württemberg 43. Konrad Theiss Verlag. Stuttgart: 9-20.

GREGG S. A. 1988. Forager and Farmers: Population Interaction and Agricultural Expansion in Prehistoric Europe. Prehistoric Archaeology and Ecology Series. The University of Chicago Press. Chicago.

GRONENBORN D. 1999. A Variation on a Basic Theme: The Transition to Farming in Southern Central Europe. Journal of World Prehistory 13: 123-210.

2003. Migration, acculturation and culture change in western temperate Eurasia, 6500-5000 cal BC. In M. Budja (ed.), 10 th Neolithic Studies. Documenta Praehistorica XXX: 79-91.

HENRARD D. 2003. Le Mésolithique du bassin de l'Ourthe (Belgique): implantation dans le paysage et néolithisation. L'Anthropologie 107: 615-644.

JADIN I. 2003. Trois petits tours et puis s'en vont... La fin de la présence danubienne en Moyenne Belgique (avec la participation de D. Cahen, I. Deramaix, A. Hauzeur, J. Heim, A. Livingstone Smith \&J. Verniers). ERAUL 109. Université de Liège. Liège.

JADIN I., CAHEN D. 2003a. Datations radiocarbones et Rubané: Pour un mariage de raison. In I. Jadin 2003: 523581.

2003b. Sites en pagaille sur le haut Geer: Darion, Oleye, Waremme-Longchamp, Hollogne-Douze Bonnier. In $I$. Jadin 2003: 191-315.

JEUNESSE C. 1998a. Pour une origine occidentale de la culture de Michelsberg? In J. Biel, H. Schlichtherle, M. Strobel, A. Zeeb (eds.), Die Michelsberger Kultur und ihre Randgebiete. Probleme der Entstehung, Chronologie und des Siedlungswesens (Kolloquium Hemmenhofen, 21-23 Feb 1997). Materialhefte zur Archäologie in BadenWürttemberg 43. Konrad Theiss Verlag. Stuttgart: 29-45.

1998b. Villeneuve-Saint-Germain, Cerny, Grossgartach, Roessen et la synchronisation entre les séquences Néolithique moyen du Rhin et du Bassin parisien. Bulletin de la Société Préhistorique Française 95: 277-285.

2000. Les composantes autochtone et danubienne en Europe centrale et occidentale entre 5500 et $4000 \mathrm{av}$. J.-C.: contacts, transferts, acculturations. In A. Richard, C. Cupillard, H. Richard, A. Thévenin (eds.), Les derniers chasseurs-ceuilleurs d'Europe occidentale. Actes 
du colloque international de Besançon, octobre 1998. Annales Littéraires 699, Série 'Environnement, sociétés et archéologie' 1. Besançon: 361-378.

2002. Armatures asymétriques, régionalisation, acculturation. Contribution à l'étude des relations entre la Rubané et la composante autochtone dans l'ouest de la sphère danubienne. In M. Otte, J. K. Kozłowski (eds.), Préhistoire de la Grande Plaine du Nord de l'Europe. Actes du Colloque Chaire Francqui interuniversitaire au titre étranger. ERAUL 99. Université de Liège. Liège: 147-165.

JEUNESSE C. 2003. Néolithique "initial", néolithique ancien et néolithisation dans l'espace centre-européen: une vision rénovée. Revue d'Alsace 129: 97-112.

JEUNESSE C., LEFRANC P., DENAIRE A., NAZE A. C. D. R. M. A. E. G. 2002/2003. Groupe de Bischheim, origine du Michelsberg, genèse du groupe d'Entzheim. La transition entre le Néolithique moyen et le Néolithique récent dans les régions rhénanes. Cahiers de l'Association pour la Promotion de la Recherche Archéologique en Alsace 18/19 (2004). Zimmersheim.

KEELEY L. H. 1992. The Introduction of Agriculture to the Western North European Plain. In A. B. Gebauer, T. D. Price (eds.), Transitions to Agriculture in Prehistory. Monographs in World Archaeology 4. Prehistory Press. Madison (Wisconsin): 81-95.

LICHARDUS J. 1976. Rössen - Gatersleben - Baalberge. Ein Beitrag zur Chronologie des mitteldeutschen Neolithikums und zur Entstehung der Trichterbecherkulturen. Saarbrücker Beiträge zur Altertumskunde 17. Bonn.

LODEWIJCKX M., BAKELS C. C. 2000. The Interaction Between Early Farmers (Linearbandkeramik) and Indigenous People in Central Belgium. BAR International Series 861 .

LOUWE KOOIJMANS L. P. 2003. The Hardinxveld sites in the Rhine/Meuse Delta, the Netherlands, 5500-4500 cal BC. In L. Larsson, H. Kindgren, K. Knutsson, D. Loeffler, A. Akerlund (eds.), Mesolithic on the Move. Oxbow Books. Oxford: 608-624.

2006. Schipluiden: a synthetic view. In L. P. Louwe Kooijmans, P. F. B. Jongste (eds.), Schipluiden, A Neolithic settlement on the Dutch North Sea coast c. 3500 cal BC. Analecta Praehistorica Leidensia 37/38. Leiden: 485-516.

in press. The gradual transition to farming in the Lower Rhine Basin. In A. Whittle, V. Cummings (eds.), Going over: the Mesolithic-Neolithic transition in north-west Europe. Cardiff.
LÜNING J. 1967. Die Michelsberger Kultur. Ihre Funde in zeitlicher und räumlicher Gliederung. Berichte der Römisch-Germanischen Kommission 48 (1968): 1-350.

LUYPAERT I., DE BIE M., VERMEERSCH P. M. 1993. Dilsen-Dilserheide III (prov. Limburg), Midden-Neolithisch aardewerk op een Laat-Mesolithisch site. Archeologie in Vlaanderen III: 7-35.

MODDERMAN P. J. R. 1988. The Linear Pottery Culture: diversity in uniformity. Berichten van de Rijksdienst voor het Oudheidkundig Bodemonderzoek 38: 63-140.

PEETERS J. H. M., SCHREURS J., VERNEAU S. M. J. P. 2001. Deel 18. Vuursteen: typologie, technologische organisatie en gebruik. In J. W. H. Hogestijn, J. H. M. Peeters (eds.), De Mesolithische en Vroeg-Neolithische vindplaats Hoge Vaart-A27 (Flevoland). Rapportage Archeologische Monumentenzorg 79. Rijksdienst voor Oudheidkundig Bodemonderzoek. Amersfoort.

PRICE T. D., BENTLEY R. A., LÜNING J., GRONENBORN D., WAHL J. 2001. Prehistoric human migration in the Linearbandkeramic of Central Europe. Antiquity 75: 593-603.

RAEMAEKERS D. C. M. 1999. The Articulation of a new Neolithic, The meaning of the Swifterbant culture for the process of neolithization in the Dutch-North German Plain; an anthropological perspective. Archaeological Studies Leiden University 3. Faculty of Archaeology. Leiden.

2001. Aardewerk en verbrande klei. In L. P. Louwe Kooijmans (ed.), Hardinxveld-Giessendam De Bruin. Een kampplaats uit het Laat-Mesolithicum en het begin van de Swifterbant-cultuur (5500-4450 v.Chr.). Rapportage Archeologische Monumentenzorg 88. Rijksdienst voor het Oudheidkundig Bodemonderzoek. Amersfoort: 117-152.

RICHARD H. (ed.) 2004. Néolithisation précoce. Premières traces d'anthropisation du couvert végétal à partir des données polliniques. Annales Littéraires de l'Université de Franche-Comté 777. Presses Universitaires de Franche-Comté. Besançon.

SCHIER W. 1993. Das westliche Mitteleuropa an der Wende vom 5. zum 4. Jahrtausend: Kulturwandel durch Kulturkontakt? In A. Lang, H. Parzinger, H. Küster (eds.), Kulturen zwischen Ost und West. Das Ost-West-Verhältnis in vor- und frühgeschichtlichter Zeit und sein Einfluss auf Werden un Wandel des Kulturraums Mitteleuropa. Festschrift G. Kossack. Akademie Verlag. Berlin: 19-59.

SCHILD R. 1998. The Perils of Dating Open-air Sandy Sites of the North European Plain. In M. Zvelebil, L. Domanska, R. Dennell (eds.), Harvesting the Sea, Farming the 
Forest. The Emergence of Neolithic Societies in the Baltic Region. Sheffield Academic Press. Sheffield: 71-76.

SCOLLAR I. 1959. Regional Groups in the Michelsberg Culture. A Study in the Middle Neolithic of West Central Europe. Proceedings of the Prehistoric Society 25: 52134.

SHENNAN S., EDINBOROUGH K. 2007. Prehistoric population history: from the Late Glacial to the Late Neolithic in Central and Northern Europe. Journal of Archaeological Science 34: 1339-1345.

TOUSSAINT M. 2002. Problématique chronologique des sépultures du Mésolithique mosan en milieu karstique. Notae Praehistoricae 22: 141-166.

TRINGHAM R. 2000. Southeastern Europe in the transition to agriculture in Europe: bridge, buffer or mosaic. In T. D. Price (ed.), Europe's First Farmers. Cambridge University Press. Cambridge: 19-56.

VAN ASSCHE M. 2005. Aperçu sur le mésolithique des régions d'Ath et de Mons (Hainaut). Amphora 83: 42-82.

2006. Substrat Mésolithique et Néolithisation des régions d'Ath et de Mons (Hainaut-Belgique). Paper presented at Fin des traditions danubiennes dans le Néolithique du Bassin parisien et de la Belgique (51004700 BC). Autour des recherches de Claude Constantin. Résumés des communications, Namur.

VAN GIJN A. L., BEUGNIER V., LAMMERS-KEIJSERS Y. 2001a. Vuursteen. In L. P. Louwe Kooijmans (ed.), Hardinxveld-Giessendam Polderweg. Een mesolithisch jachtkamp in het rivierengebied (5500-5000 v. Chr.). Rapportage Archeologische Monumentenzorg 83. Rijksdienst voor het Oudheidkundig Bodemonderzoek. Amersfoort: 119-161.

VAN GIJN A. L., LAMMERS-KEIJSERS Y., HOUKES R. 2001b. Vuursteen. In L. P. Louwe Kooijmans (ed.), HardinxveldGiessendam De Bruin. Een kampplaats uit het Laat-Mesolithicum en het begin van de Swifterbant-cultuur (5500-4450 v. Chr.). Rapportage Archeologische Monumentenzorg 88. Rijksdienst voor het Oudheidkundig Bodemonderzoek. Amersfoort: 153-191.

VANMONTFORT B. 2001. The Group of Spiere as a New Stylistic Entity in the Middle Neolithic Scheldt Basin. Notae Praehistoricae 21: 139-143.

2004. Converging Worlds, The Neolithisation of the Scheldt basin during the late fifth and early fourth millenium cal BC. PhD thesis, Katholieke Universiteit Leuven, Leuven.
2006. Can we attribute the Middle Neolithic in the Scheldt and Middle Meuse basins to the Michelsberg Culture? In P. Duhamel (ed.), Impacts interculturels au Néolithique moyen. Du terroir au territoire: sociétés et espaces. Revue Archéologique de l'Est. Suppléments 25. Société Archéologique de l'Est. Dijon: 109-116.

forthcoming. Forager-farmer connections in an 'unoccupied' land: First contact on the western edge of LBK territory. Journal of Anthroplogical Archaeology.

VANMONTFORT B., GEERTS A.-I., CASSEYAS C., BAKELS C. C., BUYDENS C., DAMBLON F., LANGOHR R., VAN NEER W., VERMEERSCH P. M. 2001/2002. De Hel in de tweede helft van het 5 de milleniumv.Chr. Een midden-Neolithische enclosure te Spiere (prov. West-Vlaanderen). Archeologie in Vlaanderen VIII (2004): 9-77.

VERHART L. B. M. 2000. Times fade away: The neolithization of the southern Netherlands in an anthropological and geographical perspective. Archaeological Studies Leiden University 66. Leiden.

2003. Mesolithic Economic and Social Changes in the Southern Netherlands. In L. Larsson, H. Kindgren, K. Knutsson, D. Loeffler, A. Akerlund (eds.), Mesolithic on the Move, Papers presented at the Sixth International Conference on the Mesolithic in Europe, Stockholm 2000. Oxford: 442-450.

VERMEERSCH P. M. 1976. Steentijdmateriaal uit het Noordelijk Hageland. Oudheidkundige Repertoria. Reeks B 11. Nationaal Centrum voor Oudheidkundige Navorsingen in België. Brussel.

1990. La transition du Mésolithique au Néolithique en Basse et Moyenne Belgique. In D. Cahen, M. Otte (eds.), Rubané et Cardial. Actes du Colloque de Liège. ERAUL 39. Université de Liège. Liège: 96-103.

2006. Reliability of the Stratigraphy and Spatial Structures of Late Pleistocene and Holocene Sites in Sandy Areas - Mesolithic-Neolithic Contacts in Central Benelux? In C.-J. Kind (ed.), After the Ice Age: Settlements, subsistence and social development in the Mesolithic of Central Europe. Materialhefte zur Archäologie in Baden-Württemberg 78. Konrad Theiss Verlag. Stuttgart: 297-303.

VERMEERSCH P. M., LAUWERS R., GENDEL P. 1992. The Late Mesolithic Sites of Brecht-Moordenaarsven (Belgium). Helinium 32: 3-77.

ZVELEBIL M. 1986. Mesolithic prelude and Neolithic revolution. In M. Zvelebil (ed.), Hunters in transition: mesolithic societies of temperate Europe and their transition to farming. Cambridge: 5-15. 
1998. Agricultural Frontiers, Neolithic Origins, and the Transition to Farming in the Baltic Basin. In M. Zvelebil, R. Dennell, L. Domanska (eds.), Harvesting the sea, Farmiong the Forest. Sheffiels Archaeological Monographs. Sheffield: 9-27.

2000. Les derniers chasseurs-collecteurs d'Europe tempérée. In A. Richard, C. Cupillard, H. Richard, A. Thévenin (eds.), Les derniers chasseurs-ceuilleurs d'Europe occidentale. Actes du colloque international de Besançon, octobre 1998. Annales Littéraires 699, Sé- rie 'Environnement, sociétés et archéologie' 1. Besançon: 379-406.

2004. The Many Origins of the LBK. In A. Lukes, M. Zvelebil (eds.), LBK Dialogues, Studies in the formation of the Linear Pottery Culture. BAR International Series. Archaeopress. Oxford: 183-205.

ZVELEBIL M., ROWLEY-CONWY P. 1984. Transition to Farming in Northern Europe: A Hunter-Gatherer Perspective. Norwegian Archaeology Review 17: 104-127. 